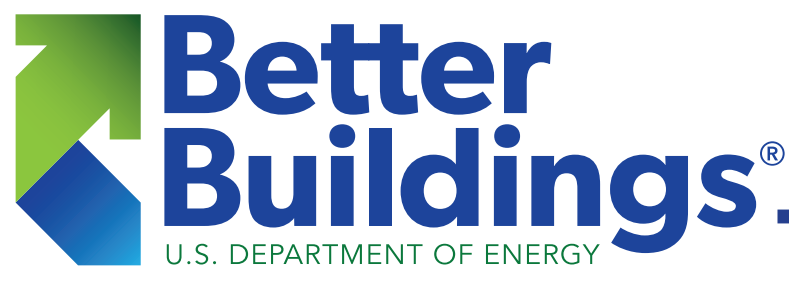

\title{
Capturing Energy Efficiency in Residential Real Estate Transactions
}

\section{Steps That Energy Efficiency Programs Can Take}

NOVEMBER 2015 


\section{Contents}

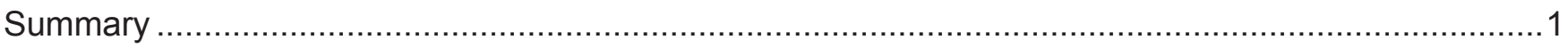

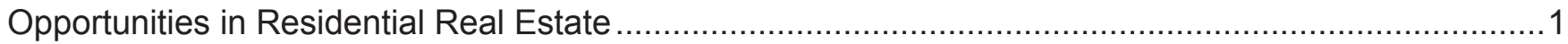

Barriers to Valuing Energy Efficiency in Residential Real Estate Transactions................................2

The Critical Role of Energy Efficiency Programs......................................................................

1. Document Information About Energy Efficiency Features in Standardized Formats......................4

2. Retain Efficiency Information and Communicate it at Time of Sale ........................................ 8

3. Support Training Resources for Real Estate Professionals...............................................10

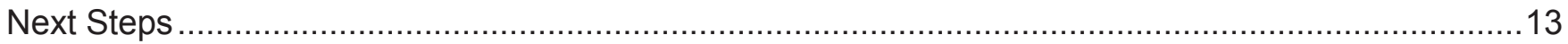

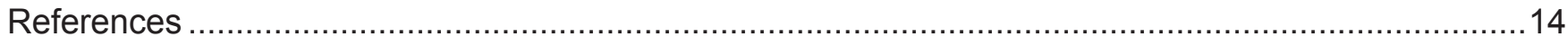

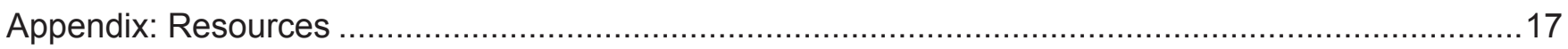

\section{Acknowledgements}

This report was prepared by Elizabeth Stuart of Lawrence Berkeley National Laboratory under contract to the U.S. Department of Energy Office of Energy Efficiency and Renewable Energy, Building Technologies Office.

The author received key direction and comments from Amanda Chiu at Energetics Incorporated and Danielle Sass Byrnett at U.S. Department of Energy. Many thanks to the energy efficiency and real estate technical experts who provided feedback: Sandra Adomatis, Adomatis Appraisal Service; Elena Alschuler, U.S. Department of Energy; Pamela Brookstein, Elevate Energy; Julie R. Caracino, New York State Energy Research and Development Authority; Jonathan Cohen, U.S. Department of Energy; Steve Dunn, U.S. Department of Energy; Emily Fadrhonc, Lawrence Berkeley National Laboratory; Joan Glickman, U.S. Department of Energy; Caroline Hazard, SRA International; Ben Hoen, Lawrence Berkeley National Laboratory; Kelsey Horton, Midwest Energy Efficiency Alliance; Ely Jacobsohn, U.S. Department of Energy; Patty Kappaz, SRA International; Gannate Khowailed, SRA International; Peter H. Larsen, Lawrence Berkeley National Laboratory; Robin LeBaron, Home Performance Coalition; Paul Mathew, Lawrence Berkeley National Laboratory; Evan Mills, Lawrence Berkeley National Laboratory; Anthony Roy, Earth Advantage; Carolyn Sarno, Northeast Energy Efficiency Partnerships; Andrew Shepherd, Energy Trust of Oregon; Amanda Stinton, National Association of Realtors; Laura Reedy Stukel, Elevate Energy; Marcia Tolentino, Build it Green; and Taylor Watkins, Watkins \& Associates Real Estate Appraisals. 


\section{Summary}

A growing number of studies suggest that some homebuyers are willing to pay a premium for energy-efficient homes. Real estate professionals are increasingly aware that today's homebuyers consider heating and cooling costs, efficient appliances, and efficient lighting to be important factors in home purchase decisions. Residential energy efficiency and real estate stakeholders, however, agree that the home resale process frequently fails to account for the value of high-performance home features. If investments in energy efficiency were more accurately reflected in home resale prices, homeowners could have greater confidence that these investments would be recouped at resale, and they might make more investments in efficiency.

While stakeholders at the local, regional and national level are undertaking a number of "green real estate" activities, key gaps persist in transmitting information about homes' energy performance to the market. Energy efficiency program administrators have a crucial role to play in bridging these gaps. This paper highlights the obstacles and opportunities within the real estate transaction value chain that program administrators are uniquely positioned to address. The paper also provides ideas for a range of relevant activities that program administrators can engage in, and examples of programs that are successfully working with real estate professionals to address the challenge of valuing energy efficiency in home resale prices.

\section{Opportunities in Residential Real Estate Transactions}

According to the U.S. Census Bureau, five million existing homes and 400,000 new homes are sold annually across the country (U.S. Census Bureau 2015). Most home sale transactions, however, do not yet adequately value efficiency. Standard practice does not make efficiency features visible to the real estate market or to homebuyers (Adams 2012, Stukel 2014). This is a key barrier to large-scale adoption of residential energy efficiency, but the large number of residential real estate transactions represents a tremendous untapped opportunity to ignite the market for efficient homes and increase demand for residential energy efficiency.

Studies in several regional markets—Austin, Texas; California; Portland, Oregon; and Seattle, Washingtonhave found that energy-efficient or green-certified homes sell for $3 \%$ to $20 \%$ more than comparable non-certified homes (Desmarais 2015, Walls et al. 2013; Kok and Kahn 2012). In addition, most U.S. homebuyers rate heating and cooling costs and efficient equipment as somewhat to very important when purchasing a home (National Association of Realtors [NAR] 2014a).

Energy efficiency and real estate stakeholders are collaborating on a range of local, regional, and national initiatives to better capture the value of efficiency in home resale transactions. One such widely recognized effort directed specifically to residential energy efficiency programs, the Value for High Performance Homes Campaign, offers comprehensive guidance for program administrators who wish to engage the real estate community to help increase demand for home energy upgrades.

In contrast, this document is a primer focusing on certain pervasive information flow gaps that energy efficiency programs are well-positioned to address. It offers steps that programs can undertake to address those gaps, from basic, relatively easy-to-implement actions to longer-term, more resource-intensive efforts. 


\section{Barriers to Valuing Energy Efficiency in Residential Real Estate Transactions}

A literature review and interviews with energy efficiency program personnel and residential real estate professionals revealed several barriers to valuing residential efficiency that energy efficiency programs are well-positioned to help address. Key barriers include the following:

- Invisibility: Many energy efficiency improvements and related safety, comfort, and durability attributes are essentially invisible (e.g., air sealing in the attic, insulation behind walls). Homebuyers cannot readily inspect them, and agents and appraisers may not ask about or understand the features.

- Lack of standardized documentation: Energy efficiency programs do not use standardized methods for documenting upgrades. Data for a specific region must be standardized in order to populate the local and regional Multiple Listing Service (MLS) searchable green data fields and provide accurate information to appraisers and buyers.

- Lack of third-party verified certification: Real estate agents strongly prefer marketing efficient homes using trusted third-party verified certifications, rather than technical information about home energy upgrades, because third-party certifications limit agents' liability when representing a home.

- Time lag between upgrades and home sale: A gap of up to 10 years or more (NAR 2014a) may pass between the time a home receives efficiency upgrades and when an agent needs that information to market the home. Homeowners typically do not have a convenient way to retain and communicate information about past upgrades to their listing agent.

- Failure to assign qualified appraisers. Mortgage market guidelines require appraisers to be fully competent to perform an appraisal on the type of property assigned, but compliance is uneven. Appraisers are usually assigned to properties based on fastest turnaround for completing appraisals and lowest appraisal price (CNT Energy 2013). Unless the borrower tells the lender that they are purchasing a high-performance home, it is highly unlikely that a qualified and certified green appraiser will be assigned, or that the home's energy efficiency features will be reflected in the appraised value.

\section{The Critical Role of Energy Efficiency Programs}

Residential energy efficiency programs, including local or state government-sponsored, regional, and ratepayer-funded programs, are uniquely positioned to address some of these barriers. Programs and their partners such as home performance contractors and builders already capture most of the data needed to make energy efficiency performance and features visible in real estate transactions.

This paper is organized into three activity areas where program administrators can address the barriers to valuing energy upgrades in real estate transactions:

1. Document energy efficiency features in standardized formats.

2. Retain energy efficiency information and communicate it at the time of sale.

3. Support training resources for real estate professionals. 
Figure 1: Overview of the High Performance Residential Real Estate Transaction System and Suggested Activities for Energy Efficiency Programs

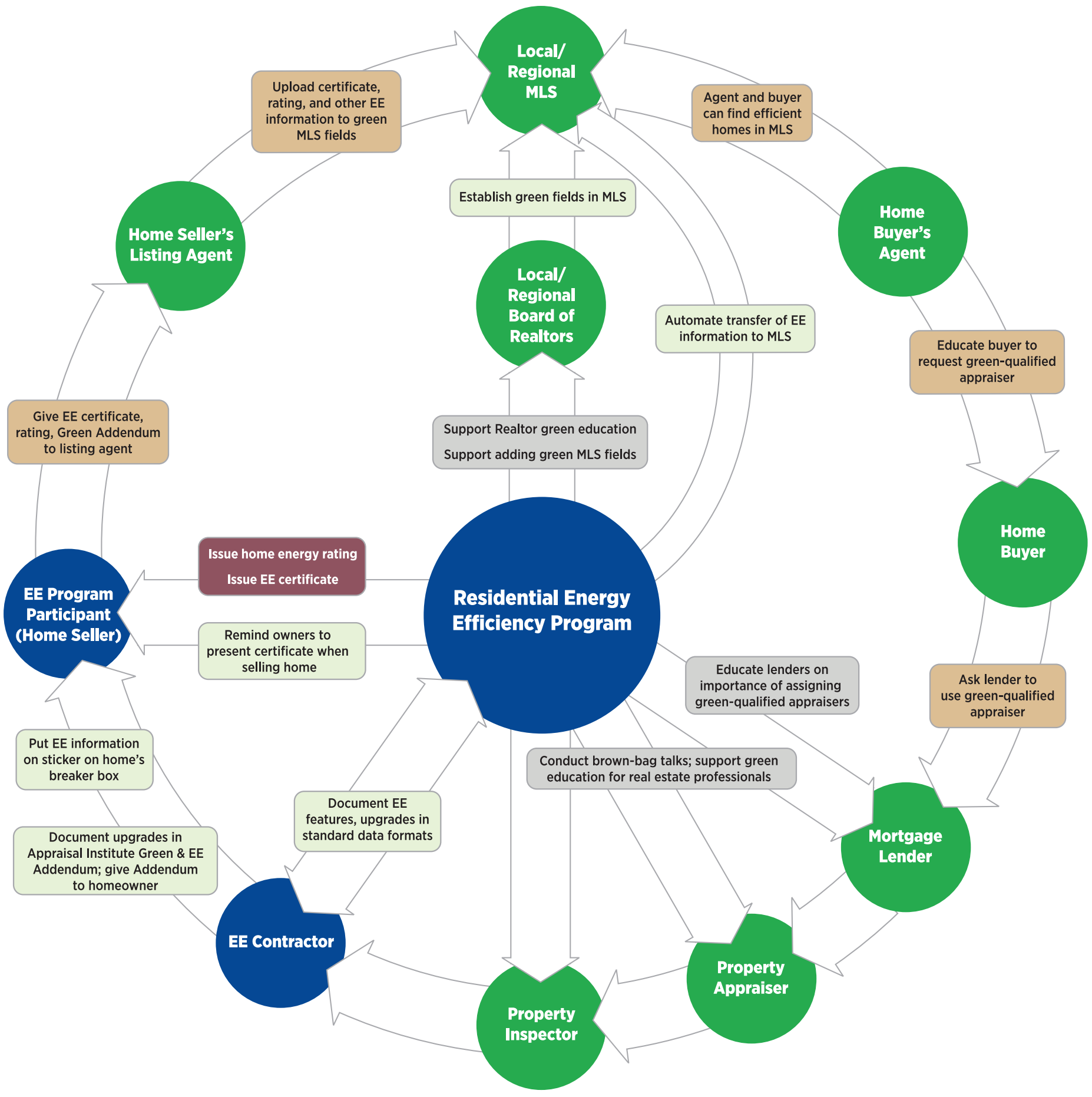

\section{Legend}

EE program and its core stakeholders

Real estate transaction stakeholders
Activity type 1: Document EE features in standardized formats

Activity type 2: Retain EE information and communicate it at time of sale

Activity type 3: Support training resources for real estate professionals

Examples of desired outcomes 
The activities range from foundational efforts easily accessible to many programs, such as ensuring energy efficiency certification information is affixed to homes' breaker boxes, to more extensive efforts, such as working with local real estate agents to establish energy efficiency or green data fields in a local MLS.

Figure 1 on page 3 presents a detailed graphical illustration of residential real estate transaction actors and the suggested activities described below that programs can take to help overcome key barriers.

The appendix to this document provides a comprehensive list of resources for energy efficiency programs, including: documentation and data standards; energy efficiency certification and rating systems; and education and training resources.

The activities a program administrator decides to undertake first will likely depend on the program's maturity and available resources, as well as the local market situation (e.g., the local inventory of high-performance homes or whether the local MLS has already established green data fields).

\section{Document Energy Efficiency Features in Standardized Formats}

Data in energy efficiency program databases is often incompatible with MLS databases. Programs already require participating contractors to submit data in order to monitor upgrades and track program impacts; however, these data are often not documented in standard formats useful to real estate professionals. In addition, many local or regional MLS databases, which serve as the central hub of information about homes for sale, do not have the capacity to accept information about a home's efficiency or "green" features.

A number of national and regional initiatives provide tools that programs can use to document homes' energy efficiency performance or features in ways that can be provided to an MLS. Several key tools are described in this section.

\section{Foundational Effort}

\section{A. Issue a home energy rating or score}

National and regional home energy rating systems provide standardized approaches to assessing and documenting a home's energy efficiency performance, including the U.S. Department of Energy's (DOE's) nationwide Home Energy Score for existing homes, the RESNET Home Energy Rating System (HERS), the Home MPG program offered by Mass Save in Massachusetts, and the Energy Performance Score offered by Energy Trust of Oregon. Several other states offer similar rating systems (see the appendix to this document for a list of home energy rating system resources). The various

\section{Certification for Energy Upgrades}

To document energy improvements for its customers, the lllinois Home Performance with ENERGY STAR (IHP) program has adapted the DOE Home Performance with ENERGY STAR (HPwES) Summary Certificate template (available in the HPwES Sponsor Guide) for its Certificate of Completion.

IHP awards two levels of home performance achievement: Silver (minimum 15\% energy savings) and Gold (30\% reduction in air leakage and other criteria). IHP Certificates are recognized with a checkbox in Midwest Real Estate Data, Illinois' largest MLS. Program participants receive certificates that include key information agents recommend for inclusion in an MLS:

- Program name and issuing organization

- Certification level

- Date of certificate issuance

- Organization that verified the completed upgrade

As required by HPwES, the IHP certificate also includes the name of the contractor firm that performed the upgrade, a list of the specific improvements completed (e.g., leakage reduction rate, $\mathrm{R}$-level of attic insulation), and date the improvements were completed.

Other home performance programs that offer certificates include the Arlington County Green Home Choice in Virginia, Efficiency Vermont, Florida Green Home Certification Standard, Local Energy Alliance Program (LEAP) in Virginia, and Missouri Home Energy Certification program. 
energy performance rating systems provide different levels of detail and comprehensiveness to meet different market needs. All provide a rating or score that can be captured in MLS fields, if the local MLS provides such fields.

"Realtors love certificates. They prefer relying on third-party verified certificates rather than technical information about upgrades, because certificates help limit their liability in regard to disclosing a home's efficiency attributes."

— Laura Stukel, Realtor and green real estate expert

\section{B. Issue certificates that leverage existing national standards}

The new homes sector has successfully relied on trusted certifications to communicate a home's efficiency status to the market (e.g., EPA's ENERGY STAR Qualified New Homes, U.S. Green Building Council's LEED designation). Energy efficiency programs can adopt a similar approach by becoming Home Performance with ENERGY STAR (HPwES) Program Sponsors and using the HPwES certificate template to develop their own versions of the HPwES Certificate of Efficiency Improvements or Certificate of Performance. The Missouri Home Energy Certification (MHEC) program and Illinois Home Performance (IHP) both offer certification for two different levels of efficiency achievement. MHEC covers both new and existing homes and IHP is specifically for existing homes.

"Realtors love certificates," says Laura Stukel, a Realtor and green real estate expert. "They prefer relying on third-party verified certificates rather than technical information about upgrades, because certificates help limit their liability in regard to disclosing a home's efficiency attributes." For energy efficiency programs that are not HPwES Sponsors, additional effort may be required, however.

\section{Program Example}

Missouri Home Energy Certification (MHEC) awards its highest level of certification (Gold) for participating homes that achieve one of several markers: a score of 8 or higher on the Home Energy Score scale, a score of 65 or lower on the HERS Index, or ENERGY STAR-qualified heating and cooling systems and a requisite number of energyefficient assets based on the 2012 International Energy Conservation Code (2012 IECC) for climate zone 4.

\section{More Extensive Effort}

\section{Work with the local MLS to add green fields}

Nearly all of the homes sold in the United States are listed in an MLS, of which there are more than 850 independently operated across the country. A green MLS contains data fields specific to high-performance homes (e.g., efficiency certification information) and acts as a critical information-sharing hub for green real estate stakeholders.

Energy efficiency programs interested in adding green fields to the MLS will want to partner with a local champion in the real estate community, (e.g., a real estate broker who is committed to selling the value of green homes). Such an ally can provide entrée to the local Board of Realtors and in turn, the MLS. Programs should also consult the NAR's Green MLS Implementation Guide, which Colorado, Atlanta, Chicago, and other communities have used to guide their green MLS implementation processes. "Greening" the MLS can begin with actions as simple as including check boxes on the MLS form to indicate an ENERGY STAR certified home, energy upgrade certificate, or energy rating label.

Energy efficiency program administrators seeking to expand participation in their programs by offering financing for upgrades may find it vital to establish green MLS fields. 


\section{Program Examples}

The Colorado Energy Office established a Residential Retrofit Working Group to increase demand for home energy upgrades. The group identified a need for energy efficiency financing options that would be sustainable after Recovery Act funds were expended. Ongoing financing would require willing lenders, which rely on appraisals for loan underwriting. In turn, appraisers must rely on available market data, much of which comes from the local MLS. Accordingly, the working group recognized the need to add green fields to MLSs across the state to provide appraisers and lenders with necessary, accurate market data about efficient homes. A subcommittee that included real estate brokers, lenders, MLS representatives, utilities, and government staff developed guidelines to propose to the 20 MLS groups across the state (Stovall 2010).

In Rhode Island, a group of real estate professionals and MLS staff turned to the Northeast Energy Efficiency Partnership (NEEP) for help establishing a green MLS. As part of that effort, NEEP provided a checklist of the first 10 recommended data fields. The list targets rating and certifications including HERS, Home Energy Score, ENERGY STAR Certified Homes, LEED for Homes, Passive House Certified, National Green Building Standard and DOE Zero Energy Ready Home.

In 2009, NAR established the Green MLS Toolkit and since that time has required MLS providers to comply with the Real Estate Transaction Standard (RETS). RETS provides standard definitions for over 500 data terms and values for the most common property attributes in the United States, as used by real estate brokers, MLSs, and software developers. More recently, NAR developed the Green MLS Implementation Guide (Guide) to help MLS programming staff add green fields. The Guide identifies a subset of the RETS fields, divided into three tiers: 1) third-party green verified information (e.g., certifications), which the Guide recommends as the most essential fields; 2) technical fields; and 3) green marketing (or unverified) fields (NAR 2014b).

Energy efficiency programs, working with other stakeholders, can use information in the Guide to help determine which data fields are feasible or necessary to add to the local MLS.

\section{$D$. Adopt interoperable transfer of home performance and energy upgrades information}

States and utilities have adopted a variety of software and data tools for compiling and analyzing home performance and energy upgrade information. As a result, many home performance contractors have needed to become proficient in multiple software programs, increasing the contractors' information technology and training costs. To address this issue, and to also serve the real estate community's need for reliable,
New Data Standards for Home Energy Upgrades: Bridging Two Worlds

Until recently, data terminology for real estate and building efficiency have not been compatible. BPI-2101 (Standard Requirements for a Certificate of Completion for Residential Energy Upgrades) and its data transfer protocol BPI-2100-S-2013 (Standard for Home Performance-Related Data Transfer, or HPXML) bridges that gap.

HPXML provides an extensible mark-up language (XML) and facilitates the exchange of information between databases. This standardized terminology allows programs to facilitate the collection of higher quality data, creates interoperability between software systems to enable data transfer across market actors, and lower the cost of data collection and data transfer. BPI-2100 and 2101 align with three other national efficiency and real estate standards:

- RETS, which defines a common standard for transferring real estate-related data

- BPI-2200-S-2013 (Standard for Home-PerformanceRelated Data Collection), which serves as a data dictionary for the home performance industry

- The Appraisal Institute's Residential Green and Energy Efficient Addendum, which provides appraisers with a standard template for collecting data about a home's "green" features 
comparable data, the Building Performance Institute (BPI) developed BPI-2101-S-2013 (BPI-2101): Standard Requirements for a Certificate of Completion for Residential Energy Upgrades. This standard defines a set of data requirements for two types of voluntary certificates:

1) Certificate of Performance, which includes an energy rating label or indication of energy consumption, such as a Home Energy Score or HERS Index score; and

2) Certificate of Energy Improvements, which documents energy efficiency measures completed in home energy upgrades, but excludes information about energy consumption.

BPI-2101 integrates with established real estate valuation tools, principally RETS (see text box on page 6). While BPI-2101 identifies a large number of energy conservation measures, energy efficiency programs do not need to use them all. Programs can use whatever subset of fields are appropriate for their particular certificate, such as assessment results, a specific measure, or details of a comprehensive upgrade (LeBaron 2014).

Implementing the new standard is a resource-intensive activity, as it may require development or retooling of program databases and interfacing with multiple contractor software programs. The BPI-2100-S-2013 Standard for Home Performance Related Data Transfer, also called Home Performance XML (HPXML), is a data protocol that enables the transfer of home performance-related data among home performance contractors, program administrators, and the real estate community (see text box on page 6). In April 2015, DOE released the HPXML Implementation Guide to help program administrators and software developers integrate BPI-2100 and 2200 into their operations and products. Several energy efficiency programs have begun pilot testing the BPI-2101 standard and HPXML.

In an effort to further support acceleration of residential energy efficiency investment, DOE's Better Buildings Initiative launched two new efforts in May 2015: the Better Buildings Home Upgrade Program Accelerator and Home Energy Information Accelerator. The Home Upgrade Program Accelerator employs data management strategies such as HPXML and other process improvements to minimize program costs while improving overall program effectiveness to help energy efficiency programs across the United States scale up to completing millions of home energy upgrades annually. The Home Energy Information Accelerator is focused on making data more readily available to the MLS and real estate stakeholders and is discussed in the next section. Energy efficiency programs interested in pursuing these activities can join the accelerators.

See the appendix to this document for links to documentation and data standards resources.

\section{Program Examples}

New York State Energy Research and Development Authority (NYSERDA) has been working to launch a BPI-2101 and HPXML pilot in 2015. Intended outcomes include: reduced contractor data collection burden; a more open market for multiple software vendors; a streamlined project approval process; and the ability to share data with the local real estate market. As an early step, NYSERDA analyzed its entire program workflow and determined which data fields to include and exclude-a process that involved many conversations with contractors and software vendors. As a result of this analysis, NYSERDA was able to identify issues and create workflow changes that provided significant early benefits, including reduced data entry burden, fewer contractor visits to the home, and faster, automated project approvals. These changes enabled more contractors to close a sale in customers' homes (Better Buildings 2015).

When Arizona Public Service (APS) implemented HPXML in late 2013, it needed a way to securely collect data from field audits with minimal data loss and errors. APS partnered with energy auditing software vendors who created a web-based portal and automation processes. The portal enabled APS to deliver and retrieve data to and from auditors in the field while the software automatically checked for errors and verified that the data complied with HPXML and APS program specifications. The automation reduced administration time for both the program and its contractors (Moore 2015). 


\section{Retain Efficiency Information and Communicate it at Time of Sale}

One of the most challenging barriers to valuing energy efficiency is the multi-year lag between the time when an energy efficiency program documents a home's efficiency and the time the home is resold. Upgrade information must be retained, possibly for many years, and communicated to the listing real estate agent and MLS when the home goes on the market, in order for the home's efficiency features to be properly marketed and valued.

Privacy regulations, often established via state legislation or state utility commission rulings, generally restrict energy efficiency programs from releasing personally identifiable information pertinent to home performance, such as a street address. Thus, in most cases, it is up to the homeowner to retain and communicate information to the listing agent. Real estate professionals report that homeowners rarely do this. Some stakeholders are undertaking long-term efforts to create a more effective process in which homeowners and homebuilders voluntarily sign a release allowing the energy efficiency program to retain the home's performance data and automatically populate an MLS listing.

Furthermore, staff turnover and short-term program cycles may jeopardize the ability of a program administrator to retain participant information that might be needed years later. Energy efficiency programs seeking ways to maintain consistent, long-term impact should work to institutionalize practices around collecting data and certifying home upgrades.

\section{Foundational Effort}

\section{A. Ensure efficiency information stays with the home}

New home programs use a simple but powerful tool that existing home programs can also use to help bridge the information gap between time of upgrade and home resale: require that participating contractors and homebuilders attach stickers documenting the energy efficiency information to the home's circuit box. ENERGY STAR Certified New Homes Version 3 requires that certification labels be affixed to the home's circuit box. In addition, a growing number of county and local governments, such as Myrtle Beach, South Carolina, require that information about efficiency upgrades for energy code compliance be affixed to the home's breaker box; however, appraiser and green real estate expert Sandra Adomatis says she rarely sees such stickers properly displayed in homes. "Manufactured homes have consistently included a sticker on the electric box for years." Adomatis says. "We can learn from their lead. [The sticker] makes it very easy for an appraiser to gather information." Adomatis recommends that at a minimum the sticker include key information found on a home energy rating or upgrade certificate.

"Manufactured homes have consistently included a sticker on the electric box for years. We can learn from their lead. [The sticker] makes it very easy for an appraiser to gather information."

- Sandra Adomatis, appraiser and green real estate expert

Both new and existing home programs can use the Appraisal Institute (Al) Residential Green and Energy Efficient Addendum

(the Addendum) to document a home's efficiency features and insure the information stays with the home. The Addendum can be completed by an appraiser, home builder, home performance contractor, home energy rater or other knowledgeable professional. In addition, some home performance software programs (e.g., RESNET Home Energy Rating Software) can automatically populate the Addendum's data fields with the results of a home energy assessment. Programs can educate home performance contractors and home builders to tell homeowners to keep the Addendum with their other important papers. 


\section{B. Engage program participants beyond the upgrade}

Programs might not have the financial resources needed to automate data transfer of energy efficiency features to an MLS. There is, however, a simpler, relatively low-cost option that may increase the chance that efficiency information will be included in a home's listing. Programs can periodically engage program participants and remind them to tout the value of their home's efficiency features when they sell the home.

\section{Program Example}

Illinois Home Performance (IHP) engages program participants in multiple ways. The IHP website advises participants to share their home performance certificate with their real estate agent when they put the home up for sale. The website also recommends asking the agent to upload the certificate to the home's listing on the MLS. To reinforce this message, in Spring of 2015, IHP sent postcards to 200 program participants that offered to replace missing certificates and reminded homeowners to use the certificates when selling the home. One person out of the 200 requested a new certificate, and because the pilot effort proved not to be a resource strain, the program expects to send the postcards to a larger number of homeowners in the upcoming year.

\section{Request homeowner permission to share data}

A key first step programs can take to provide data to agents and buyers is to obtain program participants' permission to share their home's efficiency information. DOE's Home Energy Score program provides a Customer Participation Agreement for Home Energy Score Partners to use with their customers. The agreement includes a section that asks for homeowner consent to share their Home Energy Score report with the local MLS when the home goes on the market. In one example of a program requesting homeowner consent to share data, the Colorado Energy Office Green Real Estate Initiative is working with utility-run home energy assessment programs around the state to launch a Home Energy Score rating program in 2015. The opt-in approach encourages participants to sign a waiver with the local utility, which will allow the local program to provide a home's rating information directly to the local MLS.

\section{More Extensive Effort}

\section{Ensure the home's energy efficiency is considered in appraisals}

Appraisers are unlikely to recognize the value of energy efficiency features if they have not had appropriate training (e.g., Appraisal Institute's Valuation of Sustainable Buildings Professional Development Program, Earth Advantage's Accredited Green Appraiser). Lenders or appraisal management companies typically order appraisals based on fastest turnaround and lowest appraisal cost, rather than a specific competency (CNT Energy 2013). Unless the homebuyer clearly indicates to their lender that they are purchasing a highperformance home, a qualified appraiser will likely not be assigned (Adomatis 2014).

Energy efficiency programs can help ensure accurate appraisals through several activities, including the following:

- Educate contractors or other professionals to document the home's high performance features in the Appraisal Institute Addendum.

- Advise program participants to keep the Addendum with their other home records and present it to their agent and lender when reselling the home.

- Educate real estate agents, appraisers lenders and underwriters about the Addendum and the importance of using qualified appraisers for high-performance homes.

- Educate agents to recommend that interested buyers request a green-qualified appraiser from their lender.

- Post a list of local green-qualified appraisers or link to the Appraisal Institute Valuation of Sustainable Buildings Registry, which lists green-certified appraisers across the United States. 


\section{Program Example}

Oregon-based Earth Advantage (EA) undertook efforts to produce more accurate appraisals. EA trainings provide green real estate professional certifications across the United States, and the organization has publicly posted on its website the list of appraisers who have earned EA's Accredited Green Appraiser designation. Working on behalf of Energy Trust of Oregon, the state's third-party energy efficiency program administrator, EA presents brown bag talks at the offices of local lenders' offices, educating them on the importance of assigning competent green appraisers for high-performance homes and telling them how to find qualified appraisers.

\section{E. Automate data transfer to the MLS}

Advanced approaches to data transfer will not only involve IT infrastructure and standard data protocols (e.g., BPI-2101 and HPXML) but also long-term engagement with multiple stakeholders. To support a national transition to automated data transfer, DOE's Better Buildings Initiative launched the Home Energy Information Accelerator as a collaboration among national, regional, state and local leaders in real estate and energy efficiency. The effort aims to develop automated, institutionalized systems that ensure homes' energy information reaches the MLS and other relevant points in residential real estate transactions. As of July 2015, five pilot locations (the U.S. Northeast with support from NEEP, Colorado, and the metro areas of Chicago, Portland, and Washington, D.C.) will develop and test such automation with a goal of creating replicable systems that other regions can adopt or customize. A number of energy efficiency programs across the United States have begun efforts to automate data transfer.

\section{Program Examples}

Virginia's LEAP implemented a pilot involving single-measure contractors and four different contractor software vendors that used HPXML to transfer data from the contractors to the program database. The effort succeeded technically-the data was transferred. However, LEAP was unable to achieve the scale needed to cover administrative costs without additional grant funding; so for the time being, LEAP has put automated transfer efforts on hold (Better Buildings 2015).

Energy Trust of Oregon (ETO) investigated two options for enabling automated data transfer of homes' efficiency information to their regional MLS systems. One option involved ETO transmitting data directly to MLS aggregatorsthe companies that sell data to local MLS systems. The other option entailed transferring information to county property tax records-a key information source for MLS aggregators. Both options involved technical and legal challenges. Ultimately, ETO succeeded in making arrangements with county officials to transfer homes' energy rating data to county property tax record databases.

\section{Support Training Resources for Real Estate Professionals}

While it is critical to properly document and communicate energy efficiency information to the real estate market, in order for the information to be useful, all relevant stakeholders must have the knowledge to use it effectively. Energy efficiency programs can support training for the key institutions and people that impact the value of energy efficiency in real estate transactions, including real estate brokers and agents, appraisers, home inspectors, lenders, and program contractors.

Education offerings for real estate professionals often serve different purposes (e.g., multi-day courses for earning an advanced designation, continuing education units (CEUs) required for license renewal, and additional classes for voluntary professional development). Most real estate professions require some kind of ongoing education to remain in good standing. 
Real estate schools and courses are licensed and approved at the state level. Such state authorities include the Illinois Department of Financial \& Professional Regulation, the Arizona Department of Real Estate, and the New Jersey Real Estate Commission in the Department of Banking \& Insurance, for example. Energy efficiency program administrators interested in supporting educational offerings should begin by working with members of the local Board of Realtors to understand who licenses real estate stakeholders in a given state and what the renewal requirements are.

\section{Foundational Effort}

\section{A. Conduct outreach and develop relationships with the real estate community}

Energy efficiency program administrators can develop valuable relationships by attending and giving free "brown bag" talks at local real estate offices, and to appraisers, lenders, and home inspectors. Relevant topics include: green MLS fields; energy efficiency certifications and ratings; high-performance home features that can help sell homes; information about the local inventory of high-performance homes; home energy upgrade success stories; and upcoming green trainings that offer CEUs. In addition, programs may find it helpful to partner with real estate professionals to help develop educational content and be trusted messengers in the real estate community.

\section{B. Provide recognition and affiliation}

Programs often establish trade ally networks to help homeowners hire qualified home performance contractors and to help assure the quality of upgrade work performed for program participants. Trade allies can educate homeowners about the program, and programs often provide their allies with myriad benefits, including training, recognition, and marketing support. Similarly, a program can develop affiliations with local real estate professionals in order to help homeowners and buyers find qualified green real estate agents, appraisers, inspectors, or other professionals, and also enable real estate professionals to find each other.

\section{Program Example}

Energy Trust of Oregon provided additional support and recognition for the local real estate community by developing a real estate ally designation and network, similar to its trade ally designation for approved subcontractor and builder program associates. The real estate ally designation is open to all real estate professionals who already have one of several types of green designation (e.g., Eco-Broker, NAR Green Designation, LEED Professional). Those who have earned the designation include real estate agents and brokers, appraisers, mortgage brokers, and home inspectors. ETO promotes the allies on its website, lists them in an online searchable database, provides training, and connects the real estate and other trade allies in order to increase general interest and knowledge around green real estate and energy efficiency.

\section{Partner to support classes that provide elective continuing education units}

Programs that wish to support training can partner with existing local and national training providers to produce high-quality, pre-approved training courses that will attract real estate professionals. 


\section{Program Examples}

In Chicago, the Midwest Energy Efficiency Alliance (MEEA), a non-profit energy efficiency program implementer for IHP, worked with The NAR Green Designation team and the local Main Street Organization of Realtors to offer training to local real estate professionals. After testing different approaches, they found that the most successful ways to attract agents to these trainings included offering discounted prices (e.g., $\$ 19$ for a $\$ 100$ course) and promoting the classes through email campaigns to partner utilities, contractors, and real estate agents (through the local Board of Realtors). Word-of-mouth advertising was effective in helping to promote the training. Kelsey Horton, Senior Program Associate at MEEA, says they also found that messaging was important for success. "To encourage real estate agents to see the class as a benefit and not a burden, we emphasized that the training would help them expand their expertise and build their business," Horton says.

The Colorado Energy Office worked with the Colorado Chapter of the Appraisal Institute and the Colorado Coalition of Appraisers to subsidize training for 40 residential appraisers to become certified through the Appraisal Institute's Valuation of Sustainable Buildings Program. This number represents over $10 \%$ of the national total of appraisers with that certification. The Colorado Energy Office has also sponsored about 60 trainings for real estate agents on the green MLS, and is developing a new course on the Home Energy Score. Additionally, the Colorado Energy Office is providing scholarships to home inspectors to cover the cost of BPI's Building Science Principles training and fees for participating in the BPI Rater program to enable them to qualify to become Home Energy Score Assessors.

The Vermont Green Homes Alliance provides opportunities for real estate professional education on energy efficiency using Vermont's accredited, continuing education system. Together with the Vermont Department of Public Service, the New Hampshire Office of Energy and Planning, and the Vermont Energy Investment Corporation, the Vermont Green Homes Alliance held a real estate industry symposium in fall 2015 for real estate agents, appraisers, and lenders in Vermont and New Hampshire. Continuing education courses are offered with the objective of creating a registry of green real estate professionals available to homebuyers and sellers interested in energy-efficient homes.

Columbia Water \& Light (CWL), a municipal utility in Missouri, is a Home Energy Score Partner that has been actively engaged in educating the real estate community around energy efficiency. The utility subsidizes the cost of BPI Building Science Principles (BSP) training (charging $\$ 65$ for $\$ 200$ class) for all local real estate agents. CWL holds BSP trainings twice a year and facilitates the test for the BSP Certificate of Knowledge. The utility plans to offer CEUs in the near future for real estate agents who take the training.

See the appendix to this document for more information about educational resources.

\section{More Extensive Effort}

\section{Support nationally accredited certification for real estate professionals}

Programs can also partner with local real estate organizations to offer in-depth, nationally accredited training and the opportunity for local real estate professionals to achieve national designation. Nationally recognized green professional certifications for real estate agents include:

- The NAR Green Designation. Trainings are comprised of a three-day series of courses (i.e., Green 100, 200 and 300 courses). Topics in this training series include sustainability principles, certifications and labels, green building principles, existing home upgrades, and greening your real estate business. 
- The EcoBroker Designation. Core curriculum consists of three 6-hour classes that cover health, comfort and efficiency measures, home certifications and financing, and greening your real estate business.

Several regional initiatives leverage national educational programs and add their own training courses. Local and regional trainings provide agents the added value of in-depth information about the local housing market. Such regional initiatives include:

- Earth Advantage Broker accreditation offers its own training to real estate brokers in multiple states (Alabama, Nevada, Oregon, Virginia, Washington) and satisfies the NAR's Green 100 course requirements. Graduates earn both the NAR and Earth Advantage designation.

- Build it Green, a nonprofit California program implementer, offers its own one-day course that satisfies the NAR Green 100 course requirement and offers NAR's 200 and 300 courses.

Real estate agents have many opportunities to gain CEUs at no cost. For programs in locations where green real estate is not yet well-established, offering free or subsidized classes could significantly boost attendance. Build it Green is one of several programs that uses ratepayer-funded energy efficiency program funds to attract real estate agents to trainings. Build it Green

"Realtors are a hard bunch to get in the training seat. In the past, we tried offering the training for $\$ 50$, and they were still reluctant."

— Marcia Tolentino, Build it Green currently covers the full cost of the NAR Designation three-day training ( $\$ 600$ per attendee), so agents can take the training for free.

Marcia Tolentino, Real Estate Outreach Project Manager for Build it Green, said that it's critical for the class to be free. "Realtors are a hard bunch to get in the training seat. In the past, we tried offering the training for $\$ 50$, and they were still reluctant."

\section{Next Steps}

Residential energy efficiency programs have a wide range of options and resources available to begin engaging the real estate community. The steps a program administrator starts with will likely depend on its situation and the state of the local green real estate market. Initial questions to ask include:

- Has the regional MLS established any green fields?

- Is there interest among local real estate professionals?

- Is there a growing inventory of high-performance homes?

- Are local green real estate trainings available?

- Does my program have relationships with members of the real estate community?

- Has my program established any energy efficiency certification and rating programs?

- Does my program have the authority to make participants' efficiency data available to real estate stakeholders?

- Does my program have the resources necessary to develop databases and work with software vendors?

Program administrators have a vital interest and role in contributing to accurate valuation of energy efficiency in home prices. 


\section{References}

Adams, C. 2012. Valuing Energy Efficiency in the Real Estate Community. Proceedings of the 2012 American Council for an Energy-efficient Economy (ACEEE) Summer Study on Energy Efficiency in Buildings. August. Accessed at: http://www.aceee.org/files/proceedings/2012/data/papers/0193-000209.pdf.

Adomatis, S. 2014. "The High Performance Appraisal Process Unveiled." Presentation for the Energy \& Environmental Building Alliance. September. Accessed at: http://www.eeba.org/Data/Sites/1/ conference/2014/presentations/Adomatis-The-High-Performance-Appraisal-Process-Unveiled.pdf.

Better Buildings Summit. 2015. Overcoming the Home Upgrade Tower of Babel with HPXML. Panel presentation at the 2015 Better Buildings Summit, Washington, D.C. Accessed at: http:// betterbuildingssolutioncenter.energy.gov/sites/default/files/Wednesday\%20-\%200vercoming\%20 Energy\%20Data\%20Tower\%20of\%20Babel\%20w\%20HPXML.pdf.

U.S. Census Bureau. 2015. Joint Release U.S. Department of Housing and Urban Development [news release]. January 27, 2015. Accessed at: https://www.census.gov/construction/nrs/pdf/newressales. pdf.

U.S. Census Bureau. 2013. American Housing Survey [Infographic]. Accessed at: http://www.census.gov/ programs-surveys/ahs/visualizations/home-improvements.html.

CNT Energy and National Home Performance Council. 2013. Unlocking the Value of an Energy Efficient Home. August. Accessed at: http://www.elevateenergy.org/wp/wp-content/uploads/Unlocking_the_Value_of_ an_Energy_Efficient_Home_FINAL.pdf.

U.S. Department of Energy (DOE). 2011. Residential Provisions of the 2012 International Energy Conservation Code. Building Energy Codes Program of the Building Technologies Office. July.

Desmarais, L. 2015. An Early Look at Energy Efficiency and Contributory Value. Commissioned by the Colorado Energy Office. Accessed at: http://www.colorado.gov/cs/Satellite?blobcol=urldata\&blobheader name1=Content-Disposition\&blobheadername2=Content-Type\&blobheadervalue1=inline $\% 3 B+$ filename \%3D\%22An+Early+Look+at+Energy+Efficiency.pdf\%22\&blobheadervalue2=application\%2Fpdf\&blobkey= id\&blobtable=MungoBlobs\&blobwhere $=1252053495204 \&$ ssbinary $=$ true .

Foley, Craig. 2015. The Value of Energy Efficiency in the Real Estate Market. Webinar presented on June 24, 2015. Accessed at: https://www.youtube.com/watch?v=|xQKDkxwqek\&feature=youtu.be.

Griffin, A. 2009. Certified Home Performance: Assessing the Impacts of Third Party Certification on Residential Properties. Earth Advantage Institute. May. Accessed at: https://www.earthadvantage.org/ assets/documents/AssessingMarketImpactsofThirdPartyCertification-090529.pdf.

Kok, N., M. E. Kahn. 2012. The Value of Green Labels in the California Housing Market. July. Accessed at: http://www.usgbc.org/sites/default/files/ValueofGreenHomeLabelsStudy_July2012.pdf.

LeBaron, R. 2014. "Show Them the Money." Presentation to Affordable Comfort, Inc. (ACI) Chesapeake, Rockville, MD, June 11.

Moore, R. 2015. Arizona Public Service and Salt River Project Contractors Choose OptiMiser. Accessed at: http://optimiserenergy.com/overcoming-regulatory-hurdles-with-automated-qa/.

National Association of Realtors (NAR). 2015a. Existing-home sales rebound in December, 2014 total sales finish 3 percent below 2013 [Press release]. January 23, 2015. Accessed at: http://www.realtor.org/newsreleases/2015/01/existing-home-sales-rebound-in-december-2014-total-sales-finish-3-percent-below-2013. 
NAR. 2015b. Existing-Home Sales Data. Accessed at: http://www.realtor.org/topics/existing-home-sales/data.

NAR. 2014a. Profile of Home Buyers and Sellers Highlights. Accessed at: http://www.realtor.org/topics/ profile-of-home-buyers-and-sellers.

NAR. 2014b. Green MLS Implementation Guide. Accessed at: http://greenresourcecouncil.org/sites/default/ files/2014\%20NAR\%20Green\%20MLS\%20Implementation\%20Guide.pdf.

National Association of Home Builders (NAHB). 2013. What Home Buyers Really Want. May. Accessed at: http://www.nahb.org/ /media/Sites/NAHB/SupportingFiles/8/Wha/WhatHomeBuyersWant_20130430023250. ashx?la=en.

Siniavskaia, N. 2008. Spending Patterns of Home Buyers. National Association of Home Builders, Special Studies. December. Accessed at: http://www.nahbclassic.org/generic.aspx?sectionID=734\&generic ContentID=106491\&channelID=311.

Stukel, L., R. Scheu, C. Gamba, P. Brookstein. 2014. Valuing Home Performance Improvements in Real Estate Markets. Proceedings of ACEEE 2014 Summer Study. August. Accessed at: http://www. elevateenergy.org/wp/wp-content/uploads/Valuing_Home_Performance_Improvements.pdf.

Stovall, J.K. 2010. Colorado "Greens" the MLS. Council of Multiple Listing Services article. September. Accessed at: http://www.councilofmls.com/colorado-greens-the-mls-by-john-k-stovall-vice-president-forbusiness-development-ecobroker-international/.

Stovall, J.K., J. Beldock, R. LeBaron, K.S. Rinaldi. 2011. Unlocking The Full Value of Green Homes: Why Green Multiple Listing Services are the Key to Residential Energy Efficiency. National Home Performance Council and Association of Energy and Environmental Real Estate Professionals.

Walls, M., K. Palmer, T. Gerarden. 2013. Is Energy Efficiency Capitalized into Home Prices? Evidence from Three U.S. Cities. Resources for the Future. July. Accessed at: http://www.rff.org/RFF/Documents/ RFF-DP-13-18.pdf. 


\section{APPENDIX: RESOURCES}




\section{Appendix: Resources}

\begin{tabular}{|c|c|c|c|}
\hline & Resource & Description & URL \\
\hline & BPI 2101 Standard & $\begin{array}{l}\text { Standard for documenting } \\
\text { home energy upgrade } \\
\text { information }\end{array}$ & $\begin{array}{l}\text { http://www.bpi.org/tools_ } \\
\text { downloads.aspx?selected } \\
\text { TypelD=1\&selectedID=143 }\end{array}$ \\
\hline & BPI 2100 (HPXML) & $\begin{array}{l}\text { XML protocol for transferring } \\
\text { of BPI } 2101 \text { information } \\
\text { between software systems }\end{array}$ & $\begin{array}{l}\text { http://www.bpi.org/tools_- } \\
\text { downloads.aspx?selected } \\
\text { TypelD=1\&selectedID= } \\
141\end{array}$ \\
\hline & $\begin{array}{l}\text { HPXML Implementation } \\
\text { Guide }\end{array}$ & $\begin{array}{l}\text { Guide to help program } \\
\text { administrators and software } \\
\text { developers integrate HPXML }\end{array}$ & $\begin{array}{l}\text { http://www.energystar.gov/ } \\
\text { index.cfm?c=hpxml_guide. } \\
\text { index }\end{array}$ \\
\hline & $\begin{array}{l}\text { Building Energy Data } \\
\text { Exchange Specification } \\
\text { (BEDES) }\end{array}$ & $\begin{array}{l}\text { Data exchange dictionary for } \\
\text { building characteristics and } \\
\text { energy use }\end{array}$ & $\begin{array}{l}\text { http://energy.gov/eere/ } \\
\text { buildings/building- } \\
\text { energy-data-exchange- } \\
\text { specification-bedes }\end{array}$ \\
\hline & Green the MLS Toolkit & $\begin{array}{l}\text { Technical guide to programs } \\
\text { for implementing "green" } \\
\text { fields in an MLS database }\end{array}$ & http://www.greenthemls.org/ \\
\hline $\begin{array}{l}\text { Documentation and Data } \\
\text { Standardization Initiatives }\end{array}$ & $\begin{array}{l}\text { Green MLS } \\
\text { Implementation Guide }\end{array}$ & $\begin{array}{l}\text { Provides technical details } \\
\text { MLS staff and software } \\
\text { vendors need to implement } \\
\text { green MLS fields }\end{array}$ & $\begin{array}{l}\text { http://greenresource } \\
\text { council.org/sites/default/ } \\
\text { files/2014\%20NAR\%20 } \\
\text { Green\%20MLS\%20 } \\
\text { Implementation } \\
\text { \%20Guide.pdf }\end{array}$ \\
\hline & $\begin{array}{l}\text { The Appraisal Institute } \\
\text { Residential Green } \\
\text { and Energy Efficiency } \\
\text { Addendum }\end{array}$ & $\begin{array}{l}\text { Standardized appraisal } \\
\text { form to document homes' } \\
\text { green features, ratings and } \\
\text { certifications }\end{array}$ & $\begin{array}{l}\text { https://www. } \\
\text { appraisalinstitute.org/ } \\
\text { assets/1/7/AI_820_04- } \\
\text { Residential_Green__ } \\
\text { and_Energy_Effecient_- } \\
\text { Addendum.pdf }\end{array}$ \\
\hline & $\begin{array}{l}\text { The Appraisal Institute } \\
\text { Valuation of Sustainable } \\
\text { Buildings Appraiser } \\
\text { Registry }\end{array}$ & $\begin{array}{l}\text { Directory of appraisers who } \\
\text { have completed the Valuation } \\
\text { of Sustainable Buildings } \\
\text { Professional Development } \\
\text { Program }\end{array}$ & $\begin{array}{l}\text { http://www. } \\
\text { myappraisalinstitute.org/ } \\
\text { findappraiser/green_- } \\
\text { sustainability_residential. } \\
\text { aspx }\end{array}$ \\
\hline & $\begin{array}{l}\text { Real Estate Transaction } \\
\text { Standard (RETS) }\end{array}$ & $\begin{array}{l}\text { Real estate data transfer } \\
\text { protocol; aligns with BPI } 2101 \\
\text { and BPI } 2200\end{array}$ & $\begin{array}{l}\text { http://www.realtor.org/ } \\
\text { field-guides/field-guide- } \\
\text { to-real-estate-transaction- } \\
\text { standards-rets }\end{array}$ \\
\hline & $\begin{array}{l}\text { Value for High } \\
\text { Performance Homes } \\
\text { Campaign }\end{array}$ & $\begin{array}{l}\text { Stakeholder collaborative } \\
\text { providing tools and resources } \\
\text { for energy efficiency } \\
\text { programs, contractors and } \\
\text { regional efficiency alliances }\end{array}$ & $\begin{array}{l}\text { http://www.elevateenergy. } \\
\text { org/value-high- } \\
\text { performance-homes- } \\
\text { campaign/home/ }\end{array}$ \\
\hline
\end{tabular}




\begin{tabular}{|c|c|c|c|}
\hline & Resource & Description & URL \\
\hline \multirow{12}{*}{$\begin{array}{l}\text { Documentation and Data } \\
\text { Standardization Initiatives }\end{array}$} & $\begin{array}{l}\text { U.S. DOE Home Energy } \\
\text { Information Accelerator }\end{array}$ & $\begin{array}{l}\text { National collaborative } \\
\text { to make home energy } \\
\text { information readily available }\end{array}$ & $\begin{array}{l}\text { http://www1.eere. } \\
\text { energy.gov/buildings/ } \\
\text { betterbuildings/ } \\
\text { accelerators/ }\end{array}$ \\
\hline & $\begin{array}{l}\text { U.S. DOE Home Upgrade } \\
\text { Program Accelerator }\end{array}$ & $\begin{array}{l}\text { National collaborative to } \\
\text { help streamline and increase } \\
\text { effectiveness of ratepayer- } \\
\text { funded and government- } \\
\text { sponsored residential energy } \\
\text { efficiency programs }\end{array}$ & $\begin{array}{l}\text { http://www1.eere. } \\
\text { energy.gov/buildings/ } \\
\text { betterbuildings/ } \\
\text { accelerators/ }\end{array}$ \\
\hline & $\begin{array}{l}\text { U.S. DOE Better } \\
\text { Buildings Residential } \\
\text { Solutions Center }\end{array}$ & $\begin{array}{l}\text { Repository for examples, } \\
\text { lessons and resources for } \\
\text { energy efficiency programs }\end{array}$ & http://energy.gov/rpsc \\
\hline & \multicolumn{3}{|c|}{ Certification Program Examples and Resources } \\
\hline & $\begin{array}{l}\text { Colorado Green Real } \\
\text { Estate Initiative }\end{array}$ & $\begin{array}{l}\text { Provides a guide to } \\
\text { documenting certifications } \\
\text { and ratings for a Green MLS }\end{array}$ & $\begin{array}{l}\text { https://www.colorado.gov/ } \\
\text { pacific/energyoffice/green- } \\
\text { real-estate-initiative }\end{array}$ \\
\hline & $\begin{array}{l}\text { Illinois Home } \\
\text { Performance Certificate } \\
\text { of Completion }\end{array}$ & $\begin{array}{l}\text { Two-level energy efficiency } \\
\text { certification program for } \\
\text { existing homes that leverages } \\
\text { the HPwES efficiency } \\
\text { upgrade certificate }\end{array}$ & $\begin{array}{l}\text { http://www.illinoishome } \\
\text { performance.org/certificate }\end{array}$ \\
\hline & $\begin{array}{l}\text { Missouri Home Energy } \\
\text { Certification Program }\end{array}$ & $\begin{array}{l}\text { Two-level energy efficiency } \\
\text { certification program for new } \\
\text { and existing homes }\end{array}$ & $\begin{array}{l}\text { http://energy.mo.gov/ } \\
\text { energy/mhec }\end{array}$ \\
\hline & $\begin{array}{l}\text { ENERGY STAR Certified } \\
\text { New Home }\end{array}$ & $\begin{array}{l}\text { Certification for new homes } \\
\text { built to meet ENERGY STAR } \\
\text { requirements }\end{array}$ & $\begin{array}{l}\text { http://www.energystar.gov/ } \\
\text { index.cfm?c=new_homes. } \\
\text { hm_index }\end{array}$ \\
\hline & $\begin{array}{l}\text { Home Performance with } \\
\text { ENERGY STAR }\end{array}$ & $\begin{array}{l}\text { Information and guidance for } \\
\text { energy efficiency programs } \\
\text { that wish to become a } \\
\text { HPwES program sponsor }\end{array}$ & $\begin{array}{l}\text { http://www.energystar. } \\
\text { gov/index.cfm?c=home_ } \\
\text { improvement.hpwes_- } \\
\text { sponsor_program }\end{array}$ \\
\hline & LEED for Homes & $\begin{array}{l}\text { National certification for } \\
\text { high-performance home } \\
\text { construction and renovation }\end{array}$ & $\begin{array}{l}\text { http://greenhomeguide. } \\
\text { com/program/leed-for- } \\
\text { homes }\end{array}$ \\
\hline & $\begin{array}{l}\text { National Green Building } \\
\text { Standard }\end{array}$ & $\begin{array}{l}\text { International Code Council, } \\
\text { ASHRAE, and National } \\
\text { Association of Home Builders } \\
\text { green building certification }\end{array}$ & $\begin{array}{l}\text { http://www.home } \\
\text { innovation.com/ngbs }\end{array}$ \\
\hline & $\begin{array}{l}\text { Passive House } \\
\text { Institute U.S. }\end{array}$ & $\begin{array}{l}\text { Passive home building } \\
\text { certification and training } \\
\text { organization }\end{array}$ & $\begin{array}{l}\text { http://www.phius.org/phius- } \\
\text { certification-for-buildings- } \\
\text { and-products }\end{array}$ \\
\hline
\end{tabular}




\begin{tabular}{|c|c|c|c|}
\hline & Resource & Description & URL \\
\hline \multirow{8}{*}{$\begin{array}{l}\text { Documentation and Data } \\
\text { Standardization Initiatives }\end{array}$} & $\begin{array}{l}\text { Myrtle Beach Energy } \\
\text { Efficiency Certificate }\end{array}$ & $\begin{array}{l}\text { Example of an energy } \\
\text { efficiency code compliance } \\
\text { certificate }\end{array}$ & $\begin{array}{l}\text { http://myrtlebeachhome } \\
\text { builders.org/wp-content/ } \\
\text { uploads/2013/01/ } \\
\text { Residential-Energy- } \\
\text { Efficiency-Certificate-half- } \\
\text { sheet-stickers.pdf }\end{array}$ \\
\hline & $\begin{array}{l}\text { DOE Zero Energy } \\
\text { Ready Home }\end{array}$ & $\begin{array}{l}\text { National certification for a } \\
\text { home so efficient a renewable } \\
\text { energy system can offset all } \\
\text { or most of its annual energy } \\
\text { consumption }\end{array}$ & $\begin{array}{l}\text { http://energy.gov/eere/ } \\
\text { buildings/zero-energy- } \\
\text { ready-home }\end{array}$ \\
\hline & \multicolumn{3}{|c|}{ Home Performance Rating Systems } \\
\hline & DOE Home Energy Score & $\begin{array}{l}\text { National home energy } \\
\text { performance rating system }\end{array}$ & $\begin{array}{l}\text { http://www.homeenergy } \\
\text { score.gov/ }\end{array}$ \\
\hline & $\begin{array}{l}\text { RESNET Home Energy } \\
\text { Rating System (HERS) } \\
\text { Index }\end{array}$ & $\begin{array}{l}\text { National home energy } \\
\text { performance rating system } \\
\text { based on comprehensive } \\
\text { energy assessment }\end{array}$ & http://www.resnet.us/ \\
\hline & $\begin{array}{l}\text { Energy Performance } \\
\text { Score (EPS) }\end{array}$ & $\begin{array}{l}\text { Regional home energy } \\
\text { performance rating system }\end{array}$ & $\begin{array}{l}\text { http://energytrust.org/ } \\
\text { residential/eps/default.aspx }\end{array}$ \\
\hline & $\begin{array}{l}\text { RESNET National } \\
\text { Registry Home Energy } \\
\text { Ratings Database }\end{array}$ & $\begin{array}{l}\text { Publicly accessible database } \\
\text { of HERS raters and homes } \\
\text { that have been rated }\end{array}$ & $\begin{array}{l}\text { http://www1.resnet.us/ } \\
\text { registry/ }\end{array}$ \\
\hline & Home MPG & $\begin{array}{l}\text { Mass Save's home energy } \\
\text { performance rating system }\end{array}$ & $\begin{array}{l}\text { http://www.masssave. } \\
\text { energy-performance-score. } \\
\text { com/ }\end{array}$ \\
\hline \multirow{4}{*}{ Education Resources } & \multicolumn{2}{|c|}{$\begin{array}{l}\text { Appraisal Institute Valuation of Sustainable Buildings } \\
\text { Professional Development Program }\end{array}$} & $\begin{array}{l}\text { http://www.myappraisal } \\
\text { institute.org/findappraiser/ } \\
\text { green_sustainability_ } \\
\text { residential.aspx }\end{array}$ \\
\hline & \multicolumn{2}{|c|}{$\begin{array}{l}\text { Building Performance Institute Building Science } \\
\text { Principles Certificate of Knowledge }\end{array}$} & $\begin{array}{l}\text { http://www.bpi.org/ } \\
\text { professionals_certificate. } \\
\text { aspx\#realestate }\end{array}$ \\
\hline & \multicolumn{2}{|c|}{ EcoBroker Green Designation } & $\begin{array}{l}\text { http://www.ecobroker.com/ } \\
\text { eb/ }\end{array}$ \\
\hline & \multicolumn{2}{|l|}{ Earth Advantage ${ }^{\circledR}$ Broker } & $\begin{array}{l}\text { http://www.earth } \\
\text { advantage.org/education/ } \\
\text { earth-advantage-broker }\end{array}$ \\
\hline
\end{tabular}




\begin{tabular}{|c|c|c|c|}
\hline & Resource & Description & URL \\
\hline & Earth Adva & ed Green Appraiser & $\begin{array}{l}\text { http://www.earthadvantage } \\
\text {.org/education/accredited- } \\
\text { green-appraiser-aga }\end{array}$ \\
\hline & $\begin{array}{l}\text { Build it Gre } \\
\text { Designatior }\end{array}$ & neal Estate Professional & $\begin{array}{l}\text { www.builditgreen.org/ } \\
\text { training-events/green- } \\
\text { building-professional- } \\
\text { certification } \\
\text { https://www.builditgreen. } \\
\text { org/training-events/green- } \\
\text { real-estate }\end{array}$ \\
\hline & LEED Prof & tial & $\begin{array}{l}\text { http://www.usgbc.org/ } \\
\text { credentials }\end{array}$ \\
\hline Education Resources & $\begin{array}{l}\text { National As } \\
\text { Designatior }\end{array}$ & altors (NAR) Green & $\begin{array}{l}\text { http://greenresource } \\
\text { council.org/ }\end{array}$ \\
\hline & $\begin{array}{l}\text { NAR Learn } \\
\text { Green Des }\end{array}$ & $\begin{array}{l}\text { of states that approve NAR } \\
\text { s for CEUs }\end{array}$ & $\begin{array}{l}\text { http://learninglibrary.com/ } \\
\text { AspDotNetStoreFront70/p- } \\
\text { 786-green-100-200-300- } \\
\text { bundle.aspx }\end{array}$ \\
\hline & $\begin{array}{l}\text { Illinois Dep } \\
\text { Regulation } \\
\text { schools) }\end{array}$ & $\begin{array}{l}\text { ncial and Professional } \\
\text { tate list of approved real estate }\end{array}$ & $\begin{array}{l}\text { http://www.idfpr.com/ } \\
\text { RealEstate/Education/ } \\
\text { RESCH110.asp }\end{array}$ \\
\hline & $\begin{array}{l}\text { Northeast } \\
\text { webinar pre } \\
\text { "Value of } E\end{array}$ & $\begin{array}{l}\text { Partnership (NEEP) } \\
\text { eal estate professionals: } \\
\text { in the Real Estate Market" }\end{array}$ & $\begin{array}{l}\text { https://www.youtube.com/ } \\
\text { watch?v=|xQKDkxwqek\& } \\
\text { feature=youtu.be }\end{array}$ \\
\hline
\end{tabular}



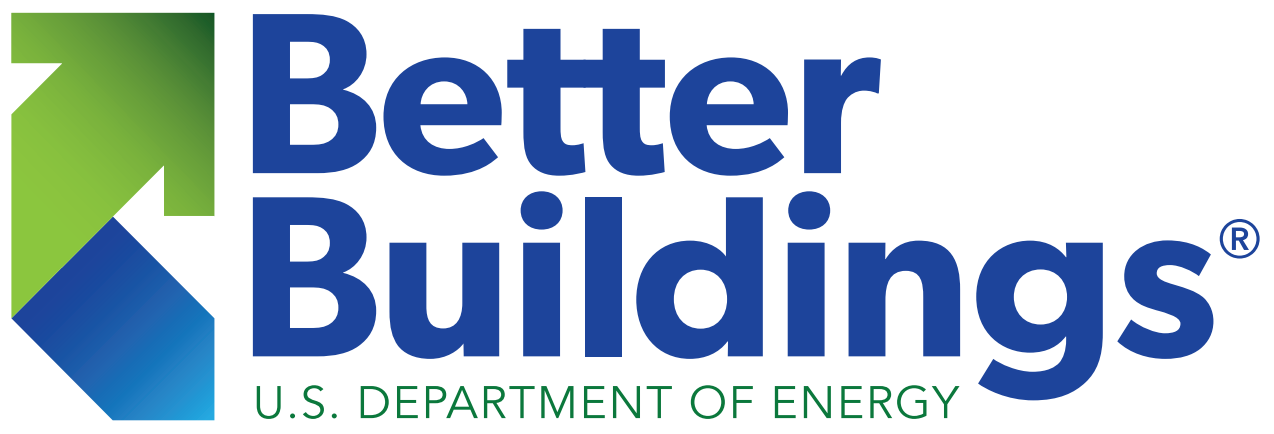